\title{
Persoonlikheidstyle as ekklesiologiese sleutel
}

\author{
C S Steyn ${ }^{1}$ \\ (Universiteit van Pretoria)
}

\section{ABSTRACT}

\section{Personality types as an ecclesiological key}

Personality types can be understood as a key in the ecclesiological positioning of members of the church. The aim of this article is to emphasise the possibilities for the church of addressing members of different personality types as well as utilising them in order to build a bridge to the world. Personality types are not only a key in understanding members but also in engaging and utilising them in the church's orientation to and task towards the world. To be a church of character in these times is a challenge in which personality types can be of help. In this article Gerben Heitink's ecclesiological matrix is combined with the sixteen distinct MBTI® personality types to form a dynamic perspective as to how specific types can be addressed and utilised in order to be a church of character.

\section{INLEIDING}

Die doel van hierdie artikel is om aan te toon dat persoonlikheidstyle ' $n$ sleutel bevat vir die ekklesiologiese posisionering van lidmate in gemeenteverband en hulle benutting deur die gemeente in die gemeenskap. Die kerk bestaan uit lidmate met verskillende persoonlikhede en ' $\mathrm{n}$ dinamiese wisselwerking daarvan wat die karakter van kerkwees bepaal. 'n Kerk met karakter sal moet ruimte maak vir lidmate met verskillende persoonlikheidstyle en dié lidmate en hulle persoonlikhede beter in die bereiking van die gemeenskap benut.

Lidmate vervul nie elkeen dieselfde rol in die gemeente nie en is nie op dieselfde wyse bruikbaar in die wisselwerking van die gemeente met die wêreld nie.

Lidmate is gawes van God aan die gemeente, sodat die gemeente ' $n$ koninkryksgawe aan die wêreld kan wees (vgl Efesiërs $4: 16 \mathrm{~b}$ NAV). Daar bestaan ' $\mathrm{n}$ veelheid van ekklesiologiese

1 Die artikel word geskryf as navorsingsvennoot van prof C J A Vos, Departement Praktiese Teologie aan die Universiteit van Pretoria. 
deelnemingsmoontlikhede (partisipasiemoontlikhede) met die implikasie dat ' $n$ kerk met karakter enersyds ruimte sal skep om lidmate dienooreenkomstig hulle persoonlikhede aan te spreek en hulle andersyds gepas sal aanwend ten opsigte van die "brugslaan" na die wêreld. "n Deel van hierdie uitdaging lê in die ekklesiologiese posisionering en benutting van persoonlikheidstyle.

\section{DIE KERK AS INSTITUUT, GEMEENSKAP EN BRUG}

Die kerk as die gemeente van Jesus Christus het teologiese identiteit wat tegelykertyd gestalte kry as 'n dinamiese organisme én 'n gestruktureerde organisasie (Pieterse 1993:158). As organisme besit die kerk pastorale funksies en as organisasie sosiale funksies. Die pastorale funksies "verseker dat die kerk aan sy doel en identiteit as liggaam van Christus beantwoord en so sy teologiese doel verwesenlik" en die sosiale funksies "verseker dat die kerk as " $n$ menslike organisasie in die moderne samelewing sinvol kan bestaan en optimaal kan funksioneer om so die kerk se sosiale doel te verwesenlik, wat weer ten nouste gekoppel is aan die kerk se teologiese doel" (Pieterse 1993:158). In ooreenstemmende verband lê Heitink (2007:37) in lyn met die werk van H Berkhof (1985:340) klem op die drievoudige karakter van die kerk naamlik die kerk as instituut, gemeenskap én bruggebeure.

Heitink (2007:37) benadruk dus die terme "gemeenskap" en "instituut" en ook, in aansluiting by die teologiese identiteit en doel van die kerk (vgl Pieterse 1993:158), die "apostolaat", die "bruggebeure" na die wêreld. Hierdie derde dimensie beklemtoon die kritiese belang van die missionêre roeping van die kerk as koninkryksinstrument en die missionale gerigtheid van gemeentewees in vandag se tyd (Steyn 2008:65). Al hierdie faktore kom vandag onder druk met die gevaar dat die kerk haar relevansie in die samelewing kan verloor en dus nie (meer) die brug kan slaan na die wêreld nie (Heitink 2007:37).

\subsection{Agt ekklesiologiese faktore}

Heitink (2007:37-40) identifiseer agt faktore wat ' $n$ invloed op die kerk uitoefen en in terme van die relevansie van die kerk in die postchristelike tyd verreken moet word. Vier faktore identifiseer hy as doelstellings van die kerk as instituut naamlik kultuur, identiteit, werfkrag en leiding en vier faktore as funksies van die kerk as gemeenskap naamlik inisiasie, partisipasie, kongegrasie en kontemplasie. So ontwerp Heitink (2007:41) 'n ekklesiologiese 
matriks met agt invalshoeke wat in 'n dinamiese wisselwerking met mekaar ageer. Hierdie matriks val in sestien verskillende kombinasies uiteen:

\begin{tabular}{|l|c|c|l|l|}
\hline $\begin{array}{l}\text { KERK AS INSTITUUT } \\
\text { KERK AS GEMEEN- }\end{array}$ & $\begin{array}{l}\text { INKULTURA- } \\
\text { SIE }\end{array}$ & $\begin{array}{c}\text { INTEGRASIE } \\
\text { (Identiteit) }\end{array}$ & $\begin{array}{l}\text { EVANGE- } \\
\text { LISASIE } \\
\text { (Werfkrag) }\end{array}$ & $\begin{array}{l}\text { ORGANI- } \\
\text { SASIE } \\
\text { (Leiding) }\end{array}$ \\
\hline $\begin{array}{l}\text { INISIASIE } \\
\text { (Godsdienstig } \\
\text { opvoeding en opleiding) }\end{array}$ & $\begin{array}{c}\text { Inkulturasie/ } \\
\text { Inisiasie }\end{array}$ & $\begin{array}{c}\text { Integrasie/ } \\
\text { Inisiasie }\end{array}$ & $\begin{array}{l}\text { Evangelisa- } \\
\text { sie/Inisiasie }\end{array}$ & $\begin{array}{c}\text { Organisasie/ } \\
\text { Inisiasie }\end{array}$ \\
\hline $\begin{array}{l}\text { PATISIPASIE } \\
\text { (Lidmaatskap) }\end{array}$ & $\begin{array}{l}\text { Inkulturasie/ } \\
\text { Partisipasie }\end{array}$ & $\begin{array}{c}\text { Integrasie/ } \\
\text { Partisipasie }\end{array}$ & $\begin{array}{l}\text { Evangelisa- } \\
\text { sie/Partisipa- } \\
\text { sie }\end{array}$ & $\begin{array}{l}\text { Organisasie/ } \\
\text { Partisipasie }\end{array}$ \\
\hline $\begin{array}{l}\text { KONGREGASIE } \\
\text { Ritueel) }\end{array}$ & $\begin{array}{l}\text { Inkulturasie/ } \\
\text { Kongregasie }\end{array}$ & $\begin{array}{c}\text { Integrasie/ } \\
\text { Kongregasie }\end{array}$ & $\begin{array}{l}\text { Evangelisa- } \\
\text { sie/Kongre- } \\
\text { gasie }\end{array}$ & $\begin{array}{l}\text { Organisasie/ } \\
\text { Kongregasie }\end{array}$ \\
\hline $\begin{array}{l}\text { KONTEMPLASIE } \\
\text { (Spiritualiteit) }\end{array}$ & Inkulturasie/ & Integrasie/ & $\begin{array}{l}\text { Evangelisa- } \\
\text { sie/Kontem- } \\
\text { plasie }\end{array}$ & $\begin{array}{l}\text { Organisasie/ } \\
\text { Kontempla- } \\
\text { sie }\end{array}$ \\
\hline
\end{tabular}

\subsection{Die kerk as instituut}

Die kerk as instituut se doelstellings verwys na die taak en doel waarvoor die kerk in die lewe geroep is, naamlik inkulturasie, integrasie, evangelisasie en integrasie (Heitink 2007:37-39).

\subsubsection{Inkulturasie}

'n Gesonde wisselwerking tussen kultuur en kerk is die belangrikste faktor wat in ons tyd stagneer en bydrae tot die kerk se irrelevansie. Die kultuur van die hedendaagse samelewing word buite die kerk om, voltrek en beoefen, asof die mens mondig geword het en die kerk nie meer nodig het nie (Heitink 2007:22, 333). Daarom noem Heitink (2007:38) die eerste ekklesiologiese doelstelling wat as operasionalisering van die kultuurfaktor dien, inkulturasie. Met inkulturasie verwys Heitink na 'n proses van aanpassing in 'n vreemde postchristelike kultuur, in teenstelling met akulturasie, die klakkelose oorneem van die omringende kultuur. Dit gaan om die vanpaste aanpassing van die kerk by die omringende kultuur/e, maar ook om die vorming van 'n kerklike teenkultuur in die soeke na balans en ter wille van ' $\mathrm{n}$ wedersydse konstruktiewe beïnvloeding (Heitink 2007:38; Steyn 2008:66).

Daarom is dit tyd vir die heroriëntasie van die kerk, en deur die kerk van die wyer gemeenskap, waarby Tijd voor heroriëntatie, die subtitel van Heitink (2007) se boek, Een kerk met karakter, aansluiting vind. Die postchristelike tydvak bied juis aan die kerk 'n 
unieke geleentheid en uitdaging om deur inkulturasie ' $n$ bydrae aan die gemeenskap te lewer ten opsigte van singewing, waardevorming, normebepaling en menswaardigheid. Die gemeenskap word dan positief aangeraak, opgebou en verander deur die kontak met die kerk. Daarom sal die kerk volgens Heitink (2007:334) ook meer aandag moet gee aan die wyse van inlywing (inisiasie), sodat mense vanuit die samelewing ook kan deel aan die geheim van die Christelike geloofsgemeenskap naamlik die "Sache Jesu".

\subsubsection{Integrasie}

Integrasie is die operasionalisering van die kerk se identiteit (Heitink 2007:38). Dit lyk nie asof die kerk mense deesdae vreeslik inspireer nie (Heitink 2007:22). Dit gaan ten diepste oor wie Jesus vir ons is en wat geloof in Jesus Christus werklik beteken. Hier word 'n antwoord gesoek op die vraag hoe die kerk te midde van " $n$ pluraliteit van geloofsgemeenskappe en 'n verskeidenheid van geestelike belewenisse, en die daarmee gepaardgaande spanning en konflik, haar identiteit kan (terug)vind? Hierdie vraag raak die diepste sin en wese van kerkwees. Waarin - of eerder in Wie - lê die identiteit van die kerk? Heitink (2007:334) se antwoord slaan op die persoon en verlossingswerk van Jesus Christus. Die identiteit van die kerk lê enkel in Christus. "De kerk staat of valt met een meerstemmige articulatie van het ene geloof in Jezus Christus. Daarin ligt haar identiteit. Want, zoals J. Moltmann opmerkt... 'Ubi Christus, ibi ecclesia', Waar Christus is - daar is kerk" (Heitink 2007:334).

Let daarop dat Christus nie in beginsel is waar die kerk is nie, maar dat die kerk is waar Christus is. Dit het geweldige implikasies vir die kerk. Die klassieke extra ecclesiam nulla salus (daar is geen heil buite die kerk om nie) kom dus onder druk en plaas die klem weer op sola Christi (die heil is in Christus alleen te vind). Christus Jesus bepaal ten diepste die identiteit van die kerk en die redding van die wêreld. Die missionale teologie van gestuurdheid (Missio Dei) sluit hierby aan. "Ons is deel van God se sending na die wêreld en $\mathrm{Hy}$ is aan die werk, met die kerk as (een van) sy instrument(e). Die kerk (elke gemeente) moet dus seker maak dat ons in Christus is, en besef dat ons ook ander geloofsgemeenskappe buite die kerk sou kon ontmoet wat deel uitmaak van die koninkryk (breër kerk) van God en onder die kragveld van die Heilige Gees lewe" (Steyn 2008:67). Dit noop die kerk om weer en oper oor die onderskeid en implikasies 
van Calvyn en Augustinus se "sigbare en onsigbare kerk" te begin dink (Heitink 2007:34).

Verder sal die kerk weer koninkryksbewus moet word en besef dat dit om God gaan wat die wêreld só liefgehad het..., en moet erns maak met die betekenis van "'Ubi Christus, ibi ecclesia', Waar Christus is - daar is kerk" waarna Heitink (2007:334) verwys. Persone buite die lidmaatskap van die kerk is dus nie bloot mense wat 'n toevlug nodig het nie, maar ook mense deur wie ons God kan ontmoet. Dit beteken dat daar wedersyds 'n dialektiese verryking tussen kerk en samelewing kan (en moet) plaasvind (Steyn 2008:45).

\subsubsection{Evangelisasie}

Die derde doelstelling van die kerk as instituut, evangelisasie, is die operasionalisering van die werfkrag van die kerk (Heitink 2007:38). Volgens Heitink (2007:22-23) ondervind die kerk weinig aanwas van buite en loop die kerk die gevaar om 'n geslote en eksklusiewe geloofsgemeenskap te word wat weinig invloed uitoefen op die samelewing buite die kerk; asof die kerk nie 'n saak met die wêreld en die wêreld nie 'n saak met die kerk het nie. Maar God het 'n saak met die kerk en die wêreld; eintlik met die wêreld via die kerk - die saak/verhaal van Jesus - die sache Jesu. Volgens Heitink (2007:61) word die postchristelike tyd gekenmerk deur ' $n$ geïndividualiseerde en gefragmenteerde lewensingesteldheid. Dit is in narratiewe taal ' $\mathrm{n}$ tydperk van kleiner verhale wat die plek inneem van die groter omvattende lewensbeskouinge (verhale). Die gevaar bestaan dat die subjektiewe verhale van individue die gemeenskaplike verhaal van Jesus kan aantas, oorskadu of selfs verdring (Steyn 2008:280).

Die werfkrag van die kerk handel dus oor die feit dat en die wyse waarop die kerk as bruggemeenskap die samelewing aanspreek. "Indien die kerk daarin slaag om aansluiting te vind by die mense in die samelewing, oefen die kerk met woord en daad invloed uit op die samelewing en groei die kerk kwantitatief sowel as kwalitatief. Indien die kerk die samelewing egter nie beïnvloed nie, raak die kerk selfsugtig na binne gekeer" (Steyn 2008:68).

\subsubsection{Organisasie}

Die vierde doelstelling, organisasie, is die operasionalisering van die leidinggewing in en deur die kerk (Heitink 2007:39). Die kerklike organiseringsvermoë en leierskap op makro- en mikrovlak kom in gedrang (Heitink 2007:23). Indien die kerk nie erns maak met haar 
leierskap op alle vlakke (na binne en buite) nie, kan die kerk nie opweeg teen of 'n indruk maak op die goedgeorganiseerde samelewing nie. Hier gaan dit oor die rapport van die geloofsgemeenskap met die omringende gemeenskap. Die kerk het 'n leidende aandeel en verantwoordelikheid in die vorming en dinamika van die samelewing.

Die vraag is in watter mate die kerk 'n aandeel en selfs oplossings vir die problematiek van die huidige samelewing bied en of en hoe die kerk positiewe leiding gee? (Steyn 2008:68). Dit handel om die bestuur, leierskap en ontwikkeling van die kerk as organisasie. Die kerk het weliswaar ' $n$ ander fokus as die wêreld wat ook in die leierskap, struktuur en bestuur van die kerk weerspieël moet word. Die struktuur van die kerk moet die geloofsinhoud en saak van die kerk (die Sache Jesu) volg en dien (Heitink 2007:335; Steyn 2008:68).

\subsection{Die kerk as gemeenskap}

Die funksies van die kerk as gemeenskap verwys na die wyse waarop die kerk in lidmate se behoeftes vervul, naamlik inisiasie, partisipasie, kongregasie en kontemplasie (Heitink 2007:37-40).

\subsubsection{Inisiasie}

Die eerste funksie is inisiasie, die operasionalisering van godsdienstige opvoeding en opleiding (Heitink 2007:39). Die kerk en haar vennote (ouers en skole) slaag al minder daarin om die volgende generasies betrokke te kry (Heitink 2007:22). 'n Faktor wat dus deeglik in die ekklesiologie verreken moet word, is dat die geloofsgemeenskap saamgestel is (of behoort te wees) uit persone van verskillende generasies (ouderdomsgroepe). Generasies bestaan uit mense wat aan ongeveer dieselfde ouderdomsgroep behoort en aan dieselfde historiese konteks blootgestel is/was (Heitink 2007:94; Steyn 2008:282). Die mensdom ontwikkel kultureel so vinnig, dat daar deesdae ongeveer elke tien jaar van 'n nuwe generasie sprake is. Codrington en Sue Grant-Marshall (2004) verwys in die verband na vyf generasies sedert 1900 naamlik die GI-generasie, die Stilgenerasie, die Baby-Boomers, die X-generasie en die Milleniumgenerasie. 'n Generatiewe aanpak verskaf 'n bruikbare ekklesiologiese lens ten opsigte van effektiewe kommunikasie en inlywing in die kerk (Steyn 2008:283). 
Dit gaan dus om die kerk as 'n deurgeegemeenskap waarin mense van jonk na oud al meer ingelyf (behoort te) word in die lewe van die gemeente. Van geslag tot geslag word geloofswaarhede en tradisies oorgedra. Die doop, kategetiese onderrig en ook eredienste is hier van kardinale belang. Volgens Heitink (2007:39) vind stagnasie al meer op hierdie terrein plaas. In terme van inisiasie, maar ook ten opsigte van inkulturasie, sal die inskakeling van verskillende generasies pertinente prakties-teologiese aandag moet geniet (Heitink 2007:72).

\subsubsection{Partisipasie}

Die tweede funksie is partisipasie (deelname), die operasionalisering van lidmaatskap (Heitink 2007:39). Die vrywilligheidskarakter van ekklesiologiese deelname vandag versus die verpligte aanvaarding van verantwoordelikheid (en gesag) van vroeër, lei tot kerkveroudering, kerkloosheid en kerklosheid (Heitink 2007:22). Dit sluit aan by die gesagskrisis van die postchristelike tyd. Lidmaatskap vra deelname aan die gemeentelike lewe en bring bepaalde verpligtinge mee. Die realiteit is dat al minder mense in ons tyd verantwoordelikheid aanvaar vir die kerklike lewe (Heitink 2007:40). Kerkwees word al meer 'n vrywilligersaak. Die kloof tussen deelname (participation) en distansiëring (distanciation) word al groter en die toepassing (application) van geloofsverantwoordelikheid al kleiner. Die samelewing (en die kerk) beweeg weg van ' $\mathrm{n}$ hiërargiese gesagstruktuur na 'n gelyke gesagstruktuur (Steyn 2008:69).

In 'n postchristelike leefwêreld moet ons daarom eerder vashou aan 'n Johannese ekklesiologie wat fokus op vriende, as aan 'n Pauliniese ekklesiologie wat fokus op ampte (Heitink 2007:334). Ook die voorheen duidelike onderskeiding tussen lidmate en nielidmate vervaag aangesien almal gelykes is. Evangelisasie word dan "vriendskapsevangelisasie" wat 'n nuwe koninkryksgerigte denkwyse vra. "n "Agterstevoor" manier van dink, van buite na binne, waarin daar vanuit die mense wat nog buite die kerk is se perspektief na die kerk en kerkwees gekyk word, met ander woorde 'n oop kerk in diens van die gemeenskap (Steyn 2008:69; vgl Heitink 2007:335). Dit gaan dus om 'n ekklesiologiese koninkryksperspektief wat ook op mense fokus wat (nog) nie deel van die Christelike geloofsgemeenskap is nie, - 'n Xeno-vriendelike en uitnodigende kerkwees (Steyn 2008:80). 


\subsubsection{Kongregasie}

Die derde funksie is kongregasie waarmee die versamelde gemeente as grondvorm van die kerk bedoel word (Heitink 2007:40). Dit gaan om die operasionalisering van die ritueelfaktor. Die kerk is 'n rituele en feesvierende gemeenskap met die erediens in die middelpunt daarvan. Heitink (2007:228-229) beskou die erediens as die hart van al die samekomste van die gemeente en dus as die hart van gemeentewees (vgl Steyn 2008:16). Dit vra dat elke erediens in ons tyd maksimaal benut sal moet word. Die hartseer is dat al minder mense deel is daarvan en dat daar in ons tyd sprake is van agteruitgang en stagnasie (Heitink 2007:23, 40). Die postchristelike tyd bied egter aan die kerk 'n nuwe geleentheid en uitdaging vir die viering van die heil in Christus (Steyn 2008:70). In die samekomste van die gemeente werk die Here deur sy Gees en sy Woord en is die gemeente waarlik ecclesia, uitgeroepenes, geroep om gesond te word en gesond te maak (Heitink 2007:335). Die versamelde gemeente vorm die sigbare liggaam van Christus en bestaan uit lidmate met verskillende persoonlikheidstyle wat in die verhoudingsnetwerk van die gemeente én in die uitreik na die wêreld verreken moet word.

\subsubsection{Kontemplasie}

Die vierde funksie, kontemplasie (geestelike oorweging), is die operasionalisering van die faktor spiritualiteit. Spiritualiteit handel oor die persoonlike geloof van lidmate (Heitink 2007:23). Baie gelowiges hardloop in ons tyd uit wind uit of verloor selfs hulle geloof. Die kerk worstel om mense in terme van hulle twyfel en geloofsworstelinge by te staan en te help om hulle geloof te bewaar (Heitink 2007:40). Geloof en geloofsonderskeiding is die diepste geheim van die kerk wat ervaring, belewing en aanbidding vra. Geloof word skaars en verander van karakter. Daar is al minder sekerheid en al meer twyfel. In kontemplasie gaan dit dus om die vorming van individuele geloof in die hart van die geloofsgemeenskap en om gebalanseerde geloofsonderskeiding te midde van 'n sekulêre samelewing (Heitink 2007:40; vgl Steyn 2008:70).

\section{DIE SESTIEN PERSOONLIKHEIDSTYLE VAN DIE MBTI ${ }^{\circledR}$}

Die skrywer maak van die psigologiese MBTI ${ }^{\circledR}$-onderskeidinge gebruik in die ekklesiologiese rolindeling. ' $n$ Basiese kennis van die Myers-Briggs Type Indicator ${ }^{\circledR}$ (MBTI ${ }^{\circledR}$ ) word in die tweede deel 
van die artikel veronderstel. Ter wille van die verstaan van lesers wat dalk nie met dié onderskeidinge bekend is nie, verskaf die skrywer ' $n$ kort oriëntasie hieromtrent in die vorm van ' $n$ basiese uiteensetting van die enkelfaktore en in aansluiting daarby 'n enkelsinnige tipering van die sestien MBTI ${ }^{\circledR}$ persoonlikheidstyle. Die ruimte laat ongelukkig nie 'n breër uiteensetting toe nie en daarom word die leser na Gifts Differing (Myers 1995) of Steyn (2008) vir verdere oriëntasie verwys.

\section{1 ' $n$ Sleutel vir ' $n$ basiese verstaan van die sestien MBTI ${ }^{\circledR}$ persoonlikheidstyle}

In navolging van Jung se psigologiese teorie is die MBTI ${ }^{\circledR}$, 'n vraelys wat persoonlikheidstylvoorkeure toets. Die rykste interpretasie van die MBTI ${ }^{\circledR}$ word in die uiteensetting van sestien unieke persoonlikheidstyle gevind (Steyn 2008:411). 'n MBTI ${ }^{\circledR}$ persoonlikheidstyl is telkens 'n vierfaktorkombinasie bestaande uit 1 - die wyse waarop iemand geënergiseer word (Ekstrovert of Introvert); 2 - die wyse waarop iemand sy wêreld waarneem en inligting bymekaarmaak (Sintuiglik of iNtuïtief), 3 - die manier op grond waarvan rasionele besluitneming plaasvind (Objektief of Waardegedrewe) en 4 - die lewenstyl wat verkies word (Gestruktureerd of Spontaan). Dié polariteite word hieronder uiteengesit aan die hand van Isabel Briggs Myers (1998:9-13) se Introduction to Type (vgl Steyn 2008:424-492).

E - 'n Ekstroverte oriëntasie: Word geënergiseer deur en is gerig op eksterne aktiwiteite, gebeure en mense.

I - 'n Introverte oriëntasie: Word geënergiseer deur en is gerig op innerlike idees, belewenisse en herinneringe.

$\mathrm{S}$ - Versameling van inligting deur sintuiglike waarneming: Maak inligting bymekaar deur hulle sintuie, rangskik dit sistematies en fokus op die hier en nou, fyn besonderhede en die realiteit.

$\mathrm{N}$ - iNtuïtiewe waarneming: Versamel inligting deur te fokus op die wyer perspektief (toekoms), patrone en die verwantskappe en samehang tussen feite.

$\mathrm{T}$ - Objektiewe besluitneming: Neem besluite op grond van logiese, objektiewe en kliniese beoordeling.

F - Waardegedrewe (subjektiewe) besluitneming: Neem besluite op grond van waardes en belewenisse wat vir ander mense en hulleself belangrik is. 
J - Gestruktureerde lewenstyl: Verkies 'n gestruktureerde, beslissende, afhandelende lewenstyl met duidelike voorkeure en afkeure en ' $n$ kritiese lewensingesteldheid.

$\mathrm{P}$ - Spontane lewenstyl: Verkies 'n spontane, aanpasbare en oop lewenstyl met buigsaamheid na die eis van omstandighede en ruimte vir laaste-minuut moontlikhede.

\section{3 'n Enkelsinnige tipering van die sestien MBTI ${ }^{\circledR}$ persoonlikheidstylvoorkeure}

- $\quad I S T J$ - Die ISTJ is 'n introvert met sintuiglike waarneming, objektiewe besluitneming en 'n georganiseerde lewenstyl.

- $\quad I S F J$ - Die ISFJ is 'n introvert met sintuiglike waarneming, waardegedrewe besluitneming en 'n georganiseerde lewenstyl.

- $\quad I N F J$ - Die INFJ is 'n introvert met intuïtiewe waarneming, waardegedrewe besluitneming en 'n georganiseerde lewenstyl.

- $\quad I N T J$ - Die INTJ is 'n introvert met intuïtiewe waarneming, objektiewe besluitneming en 'n georganiseerde lewenstyl.

- $\quad I S T P$ - Die ISTP is 'n introvert met sintuiglike waarneming, objektiewe besluitneming en 'n aanpasbare lewenstyl.

- $\quad I S F P$ - Die ISFP is 'n introvert met sintuiglike waarneming, waardegedrewe besluitneming en 'n aanpasbare lewenstyl.

- $\quad I N F P$ - Die INFP is 'n introvert met intuïtiewe waarneming, waardegedrewe besluitneming en 'n aanpasbare lewenstyl.

- $\quad I N T P$ - Die INTP is 'n introvert met intuïtiewe waarneming, objektiewe besluitneming en 'n aanpasbare lewenstyl.

- $\quad$ ESTP - Die ESTP is 'n ekstrovert met sintuiglike waarneming, objektiewe besluitneming en 'n aanpasbare lewenstyl.

- $\quad E S F P$ - Die ESFP is 'n ekstrovert met sintuiglike waarneming, waardegedrewe besluitneming en 'n aanpasbare lewenstyl.

- $\quad E N F P$ - Die ENFP is 'n ekstrovert met intuïtiewe waarneming, waardegedrewe besluitneming en 'n aanpasbare lewenstyl.

- $\quad$ ENTP - Die ENTP is 'n ekstrovert met intuitiewe waarneming, objektiewe besluitneming en 'n aanpasbare lewenstyl.

- $\quad$ ESTJ - Die ESTJ is 'n ekstrovert met sintuiglike waarneming, objektiewe besluitneming en 'n georganiseerde lewenstyl. 
- $\quad E S F J$ - Die ESFJ is 'n ekstrovert met sintuiglike waarneming, waardegedrewe besluitneming en 'n georganiseerde lewenstyl.

- $\quad E N F J$ - Die ENFJ is 'n ekstrovert met intuïtiewe waarneming, waardegedrewe besluitneming en 'n georganiseerde lewenstyl.

- $\quad E N T J$ - Die ENTJ is 'n ekstrovert met intuïtiewe waarneming, objektiewe besluitneming en 'n georganiseerde lewenstyl.

\section{PSIGOLOGIES-EKKLESIOLOGIESE VERBINDING}

Dit is nie ' $n$ eenvoudige taak om ' $n$ ekklesiologiese matriks en ' $n$ psigologiese matriks met mekaar in verband te bring nie. Die skrywer poog om, te midde van 'n hele aantal moontlikhede, die mees waarskynlike posisie asook die mees waarskynlike rol wat verskillende lidmate in terme van hulle persoonlikheidstyle in die geloofsgemeenskap kan inneem, te verwoord.

\subsection{Beskrywing en motivering vir die koppeling}

Die skrywer maak gebruik van die Energisering-Lewenstyl (E/I-J/P) kombinasies en die Waarneming-Besluitneming (S/N-T/F) kombinasies. Die Energisering-Lewenstyl kombinasies verklap iets van mense se houding, ingesteldheid en reaksie ten opsigte van die buitewêreld, hetsy ekstrovert of introvert en planmatig of spontaan. Hierdie kombinasies dui aan hoe mense verandering hanteer of bestuur (Myers 1998:32). Dit impliseer algemene asook spesifieke veranderinge en vernuwing in die erediens, gemeente en samelewing (Steyn 2008:402, 557). Die Waarneming-Besluitneming kombinasies verklap die wyses van inligtingversameling en die hantering daarvan, hetsy sintuiglik of intuitief en objektief of subjektief (waardegedrewe). Die verstaan van hierdie kombinasies dui aan hoe om mense se belangstellings, beroepskeuses en leerstyle beter te kan begryp en hoe mense kommunikeer en inligting oordra (Myers 1998:33; Coetzee 1997:61). Volgens Hirsh en Kise (1997:25) is ST's prakties en logies, SF's simpatiek en vriendelik, NF's entoesiasties en wys en NT's logies en vindingryk.

\subsection{Kombinasies van Energie en Lewenstyl}

Die persoonlikheidskombinasies van Energie en Lewenstyl val uiteen in vier moonlikhede naamlik Beslissende Introverte (IJ's), Aanpasbare Introverte (IP's), Aanpasbare Ekstroverte (EP's) en Beslissende Ekstroverte (EJ's) (Steyn 2008:402-403, 557-558). 


\subsubsection{Beslissende Introverte en Integrasie}

IJ's (ISTJ, ISFJ, INFJ en INTJ) vind aansluiting by die Integrasiedoelstelling. IJ's is die stil, sterk draers van identiteit met definitiewe innerlike oortuigings. Hoewel terughoudend is IJ's baie seker van wat en in Wie hulle glo en het dit reeds in hulle beplande lewenswyse geïntegreer. Daarom vorm hulle die stille ruggraat van 'n gemeente se identiteit. IJ's leef hulle geloof op 'n praktiese, stil manier uit en word nie maklik van koers af gebring deur eksterne faktore nie.

\subsubsection{Aanpasbare Introverte en Inkulturasie}

IP's (ISTP, ISFP, INFP en INTP) vind aansluiting by die Inkulturasie-doelstelling. IP's is ongekompliseerde, nuuskierige, aanpasbare persone wat op hulle eie tyd aanpas, wat ' $n$ goeie kombinasie is ten opsigte van inkulturasie - om enersyds by die omringende kultuur aan te pas maar andersyds ook (indien nodig) ' $\mathrm{n}$ teenkultuur of subkultuur te vorm. Hulle sal nie hulle opinie op ander afdwing nie, maar ook nie sonder meer sonder slag of stoot konformeer nie.

\subsubsection{Aanpasbare Ekstroverte en Evangelisasie}

EP's (ESTP, ESFP, ENFP en ENTP) vind aansluiting by die Evangelisasie-doelstelling. EP's is gerig na buite en fokus op netwerke en interaksie. Verder is hulle spontaan en uitgaande en slaan maklik ' $n$ brug na die buitewêreld. EP's is ook aanpasbaar en sal maklik met vreemdelinge skakel en meng. EP's is goeie motiveerders wat verskeie mense trek en selfs met mekaar versoen.

\subsubsection{Beslissende Ekstroverte en Organisasie}

EJ's (ESTJ, ESFJ, ENFJ en ENTJ) vind aansluiting by die Organisasie-doelstelling. EJ's is uitgaande, aksiegerigte persone wat spontaan en sterk leiding neem en administreer. Hulle is goeie beplanners en organiseerders wat sekerheid en sekuriteit aan voornemende nuwe lidmate bied en ook duidelike rolverwagtinge omskryf.

\subsection{Kombinasies van Waarneming en Besluitneming}

Die kerk as gemeenskap beskik oor spesifieke funksies wat aan die konkrete behoeftes van lidmate moet voorsien (Heitink 2007:37, 39). Gekoppel met die funksies van waarneming $(\mathrm{S} / \mathrm{N})$ en besluitneming $(\mathrm{T} / \mathrm{F})$ het verskillende persoonlikhede unieke bydraes om aan ' $\mathrm{n}$ 
geloofsgemeenskap te lewer. NT's fokus meer op teoretiese en prestasiegerigte take en daarom op die strategieë en strukture van die geloofsgemeenskap, terwyl SF's praktiese hulp, betrokkenheid en dienslewering aan medegelowiges bied. ST's fokus op die hier en nou, op tradisies, skedules en realiteit, terwyl NF's op 'n kreatiewe manier mense help om geestelik te groei en verbeeldingryk en visioenêr op die toekoms van die geloofsgemeenskap gerig te word (Hirsh \& Kise 1997:25-26).

\subsubsection{ST's en Inisiasie}

ST's (ISTJ, ESTJ, ISTP en ESTP) vind aansluiting by die Inisiasiefunksie. Volgens Coetzee (1997:61) fokus ST's op logiese, duidelike en feitelike kommunikasie. ST's lewer bydraes in die kerk deur hulle gefundeerdheid van die geestelike in die realiteit; deur die gebruik van logika en gesonde verstand asook hulle klem op die waarde van geloofstradisies. As ouers of kategete sal hulle gemaklik die christelike geloofswaardes en -tradisies van die kerk oorlewer. Verder konsentreer ST's op die praktiese, realistiese en daaglikse toepassing van spiritualiteit (Hirsh \& Kise 1997:27; vgl Steyn 2008:560). Volgens Hirsh en Kise (1997:27) is ST's ook betrokke by die definiëring van gemeenskaplike standaarde en beginsels wat die inisiasie van lidmate in die kerk sal dien. ST's is verantwoordelike persone wat hulle verpligtinge getrou nakom en kongruent leef met wat hulle glo en sê. Hulle stel ' $n$ duidelike voorbeeld om na te volg, wat ' $n$ vereiste is by mense wat onderrig gee en by ouerskap. ST's verskaf duidelike, stap-vir-stap instruksies en praktiese redes om iets te doen (Steyn 2008:560).

\subsubsection{SF's en Kongregasie}

SF's (ISFJ, ESFJ, ISFP en ESFP) vind aansluiting by die Kongregasie-funksie. SF's is praktiese, plat op die aarde lidmate wat met persoonlike warmte en omgee op die medegelowiges reageer. Hulle is geneig om simpatiek en vriendelik te wees en hulleself uit te leef in praktiese dienswerk aan ander. SF's neem graag saam met ander deel aan kerklike aktiwiteite en skep 'n aangename atmosfeer vir medegelowiges. SF's verskaf vriendelike interaksie en aanvaarding wat die gemeente saambind en gee geredelik simpatie, ondersteuning en individuele erkenning (Steyn 2008:560). SF's wys hulle toewyding op tasbare en sigbare maniere en lewer bydraes in die geloofsgemeenskap deur samewerking en harmonie na te streef; deernisvol die behoeftes van ander lidmate aan te spreek en deur ' $n$ 
vriendelike en verwelkomende atmosfeer in die gemeente te bewerk (Hirsh \& Kise 1997:27; vgl Steyn 2008:560-561). Volgens Hirsh en Kise (1997:27) gee SF's ook aandag aan die fyner besonderhede van geestelike feesdae of eredienste en poog hulle om ' $n$ geloofsgemeenskap te bou waarin mense waardeer, ondersteun, gekoester en liefgehê word. SF's neem die persoonlike en emosionele belewenisse van mense in ag en raak betrokke om ' $n$ duidelike verskil in ander se lewens te maak. Hulle verkies warm, interpersoonlike verhoudings waarin geloof kan groei (Steyn 2008:561).

\subsubsection{NF's en Partisipasie}

NF's (INFJ, ENFJ, ENFP en INFP) vind aansluiting by die Partisipasie-funksie. NF's slaag daarin om medegelowiges te betrek in kreatiewe deelname. NF's fokus op die verskuilde potensiaal van mense en is geneig om begrypend en entoesiasties te wees en hulleself uit te leef deur mense te verstaan en aan te moedig. Hulle stel belang in nuwe maniere om mense te verstaan en in simboliese en metaforiese aktiwiteite (Steyn 2008:561-562). Volgens Coetzee (1997:61) fokus NF's op die verskaffing en bespreking van idees, die toekoms en menslike toestande. Hulle maak gebruik van metafore en voorbeelde wat fokus op mense se emosionele behoeftes. NF's word gekenmerk deur vriendelikheid, entoesiasme, humor en individuele erkenning (Steyn 2008:561-562). NF's lewer 'n bydrae in die geloofsgemeenskap deur die visioenering van die potensiaal van mense; deur kommunikatiewe kreatiwiteit toe te pas en deur die aspirasies, ideale en waardes van die geloofsgemeenskap te koester. NF's konsentreer daarop om ander te inspireer om hulle ideale na te jaag en kry mense so betrokke. Hulle beywer hulle vir die opbou van die breër samelewing en inspireer ander om met integriteit en betekenis te leef (Hirsh \& Kise 1997:27).

\subsubsection{NT's en Kontemplasie}

NT's (INTJ, ENTJ, ENTP en INTP) vind aansluiting by die Kontemplasie-funksie. NT's fokus op moontlikhede, pas die teoretiese konsepte en sisteme toe, is geneig om logies en analities te wees en leef hulleself uit in teoretiese en tegniese raamwerke. NT's stel belang in omvattende teoretiese verklarings oor die wêreld en die lewe (Steyn 2008:562). Volgens Hirsh \& Kise (1997:27) lewer NT's ' $n$ bydrae deur die konseptualisering van oplossings vir ingewikkelde probleme, 'n klem op uitnemendheid en deur modelle 
te ontwerp met die oog op die langtermynbeplanning van die geloofsgemeenskap. NT's konsentreer op die definiëring van die waarheid en op geloofsonderskeiding. Volgens Steyn (2008:562-563) is NT's baie nugter en oorredend en kan dikwels beide kante van 'n saak beredeneer. NT's kan medegelowiges behulpsaam wees in die oorweging van geestelike beginsels. NT's is nie bang vir argumente en redenasies nie, inteendeel vir NT's is bespreking of selfs debattering belangrik om hulle soeke na antwoorde te bevredig. NT's verwag en bied vindingrykheid om verweefde geestelike problematiek op te los (Hirsh \& Kise 1997:27). NT's poog om standhoudende en effektiewe langtermynverandering teweeg te bring en om paradigmas te skuif en geloofsteorieë te ondersoek (Steyn 2008:563). Daarom kan NT's met groot vrymoedigheid ' $n$ rol speel in kontemplasie.

\subsection{Ekklesiologiese posisionering}

Vanuit bogenoemde val elkeen van die sestien MBTI ${ }^{\circledR}$ persoonlikheidstyle ten opsigte van ekklesiologiese posisionering so uiteen:

\subsubsection{Ekklesiologiese posisionering van die ISTJ}

Die ISTJ sluit die nouste aan by die Integrasie-doelstelling en Inisiasie-funksie. Die ISTJ-lidmaat het 'n aandeel aan die konkretisering van die identiteit van die geloofsgemeenskap en om ander individue ten opsigte van lidmaatskap deur middel van opleiding en kategetiese onderrig in die gemeente in te lyf ( $\mathrm{vgl}$ Steyn 2008:577).

\subsubsection{Ekklesiologiese posisionering van die ISFJ}

Die ISFJ sluit die nouste aan by die Integrasie-doelstelling en Kongregasie-funksie. Die ISFJ-lidmaat het 'n aandeel aan die konkretisering van die identiteit van die gemeente asook om medeverantwoordelikheid te aanvaar om ander lidmate in die lief en die leed van die geloofsgemeenskap te laat deel (vgl Steyn 2008:583).

\subsubsection{Ekklesiologiese posisionering van die INFJ}

Die INFJ sluit die nouste aan by die Integrasie-doelstelling en die Partisipasie-funksie. So het die INFJ-erediensganger 'n aandeel aan die konkretisering van die identiteit van die christelike geloofsgemeenskap asook om medeverantwoordelikheid te aanvaar 
om ander mense as individuele lidmate by die gemeente in te skakel (vgl Steyn 2008:588).

\subsubsection{Ekklesiologiese posisionering van die INTJ}

Die INTJ sluit die nouste aan by die Integrasie-doelstelling en die Kontemplasie-funksie. So het die INTJ-lidmaat 'n aandeel aan die konkretisering van die christelike identiteit van die geloofsgemeenskap waarin nugtere geloofsonderskeiding toegepas kan word (vgl Steyn 2008:594).

\subsubsection{Ekklesiologiese posisionering van die ISTP}

Die ISTP sluit die nouste aan by die Inkulturasie-doelstelling en die Inisiasie-funksie. So lewer die ISTP-lidmaat 'n kosbare bydrae aan die gemeente om deel van die bruggemeenskap na die omringende kultuur te vorm (sonder om daardeur oorweldig te word) asook om ander individue deur middel van opleiding en kategetiese onderrig ten opsigte van lidmaatskap in die kerk in te lyf (vgl Steyn 2008:599).

\subsubsection{Ekklesiologiese posisionering van die ISFP}

Die ISFP sluit die nouste aan by die Inkulturasie-doelstelling en die Kongregasie-funksie. So lewer die ISFP-lidmaat 'n kosbare bydrae om deel van die bruggemeenskap na die omringende kultuur te vorm. Dit impliseer verder dat die gemeente die ISFP-lidmate met vrug kan gebruik om medeverantwoordelikheid daarvoor te aanvaar om ander individue te laat deel in die lief en die leed van die gemeente (vgl Steyn 2008:605).

\subsubsection{Ekklesiologiese posisionering van die INFP}

Die INFP sluit die nouste aan by die Inkulturasie-doelstelling en die Partisipasie-funksie. So lewer die INFP-lidmaat 'n kosbare bydrae om deel van die bruggemeenskap na die omringende kultuur te vorm asook om medeverantwoordelikheid te aanvaar om ander mense as individuele lidmate by die gemeente in te skakel en te verwelkom (vgl Steyn 2008:610).

\subsubsection{Ekklesiologiese posisionering van die INTP}

Die INTP sluit die nouste aan by die Inkulturasie-doelstelling en die Kontemplasie-funksie. So lewer die INTP-lidmaat 'n kosbare bydrae om deel van die bruggemeenskap na die omringende kultuur te vorm (sonder om daardeur oorweldig te word) asook in die vestiging van 
'n eie gemeentekultuur waarin nugtere geloofsonderskeiding toegepas word (vgl Steyn 2008:616).

\subsubsection{Ekklesiologiese posisionering van die ESTP}

Die ESTP sluit die nouste aan by die Evangelisasie-doelstelling en die Inisiasie-funksie. Dit beteken dat die gemeente die ESTP-lidmaat met vrug kan gebruik in die evangelisering van die gemeenskap asook om potensiële lidmate deur middel van opleiding en kategetiese onderrig in die gemeente en ook ten opsigte van lidmaatskap in die kerk in te lyf (vgl Steyn 2008:621).

\subsubsection{Ekklesiologiese posisionering van die ESFP}

Die ESFP sluit die nouste aan by die Evangelisasie-doelstelling en die Kongregasie-funksie. Dit beteken dat die gemeente die ESFPlidmaat met vrug kan gebruik in die evangelisering van die gemeenskap asook om medeverantwoordelikheid daarvoor te aanvaar om ander individue te laat deel in die lief en die leed van die geloofsgemeenskap (vgl Steyn 2008:627).

\subsubsection{Ekklesiologiese posisionering van die ENFP}

Die ENFP sluit die nouste aan by die Evangelisasie-doelstelling en die Partisipasie-funksie. Dit beteken dat die gemeente die ENFPlidmaat met vrug kan gebruik in die evangelisering van die gemeenskap asook om medeverantwoordelikheid te aanvaar om ander mense as individuele lidmate van die gemeente in te skakel en te verwelkom (vgl Steyn 2008:632).

\subsubsection{Ekklesiologiese posisionering van die ENTP}

Die ENTP sluit die nouste aan by die Evangelisasie-doelstelling en die Kontemplasie-funksie. Dit beteken dat die gemeente die ENTPlidmaat met vrug kan gebruik in die evangelisering van die gemeenskap asook in die beoefening van geloofsonderskeiding deur lidmate in die hedendaagse tyd (vgl Steyn 2008:638).

\subsubsection{Ekklesiologiese posisionering van die ESTJ}

Die ESTJ sluit die nouste aan by die Organisasie-doelstelling en die Inisiasie-funksie. So lewer die ESTJ-lidmaat 'n kosbare bydrae in die organisering van die gemeente en ten opsigte van die leidinggewing in die breër gemeenskap asook om ander individue deur middel van opleiding en kategetiese onderrig in die gemeente en in die lidmaatskap van die kerk in te lyf (vgl Steyn 2008:644). 


\subsubsection{Ekklesiologiese posisionering van die ESFJ}

Die ESFJ sluit die nouste aan by die Organisasie-doelstelling en die Kongregasie-funksie. So lewer die ESFJ-lidmaat 'n kosbare bydrae in die organisering van die gemeente en die breër samelewing, asook om medeverantwoordelikheid daarvoor te aanvaar om ander individue te laat deel in die lief en die leed van die geloofsgemeenskap (vgl Steyn 2008:649).

\subsubsection{Ekklesiologiese posisionering van die ENFJ}

Die ENFJ sluit die nouste aan by die Organisasie-doelstelling en die Partisipasie-funksie. So lewer die ENFJ-lidmaat 'n kosbare bydrae ten opsigte van die organisering van die gemeente en die breër samelewing, asook om medeverantwoordelikheid te aanvaar om ander mense as individuele lidmate van die gemeente in te skakel (vgl Steyn 2008:655).

\subsubsection{Ekklesiologiese posisionering van die ENTJ}

Die ENTJ sluit die nouste aan by die Organisasie-doelstelling en die Kontemplasie-funksie. So lewer die ENTJ-lidmaat 'n kosbare bydrae in die organisering van die gemeente en die breër samelewing, asook in die vorming en beoefening van geloofsonderskeiding by lidmate in vandag se tyd (vgl Steyn 2008:660).

\section{5 'n Grafiese weergawe van die koppeling tussen die ekklesiologiese- en psigologiese matriks}

\begin{tabular}{|l|l|l|l|l|}
\hline $\begin{array}{l}\text { KERK AS INSTITUUT } \\
\text { KERK AS GEMEEN- } \\
\text { SKAP }\end{array}$ & $\begin{array}{l}\text { INKULTU- } \\
\text { RASIE }\end{array}$ & $\begin{array}{l}\text { INTEGRA- } \\
\text { SIE }\end{array}$ & $\begin{array}{l}\text { EVANGELISA- } \\
\text { SIE }\end{array}$ & ORGANISASIE \\
\hline INISIASIE & ISTP & ISTJ & ESTP & ESTJ \\
\hline PARTISIPASIE & INFP & INFJ & ENFP & ENFJ \\
\hline KONGREGASIE & ISFP & ISFJ & ESFP & ESFJ \\
\hline KONTEMPLASIE & INTP & INTJ & ENTP & ENTJ \\
\hline
\end{tabular}

\section{SLOT}

Met hierdie artikel het die skrywer aangetoon dat die kerk, om vandag ' $n$ kerk van karakter te kan wees, haar lidmate met hulle unieke persoonlikheidstyle doelmatig en funksioneel ekklesiologies kan en moet aanwend. Die skrywer het Heitink se ekklesiologiese matriks van die kerk as instituut en gemeenskap funksioneel met die psigologiese matriks van die MBTI ${ }^{\circledR}$ in verband gebring, sodat die 
kerk in vandag se tyd in terme van haar apostolaatskap werklik ' $n$ brug na die wêreld kan wees. Elke lidmaat het hierin "n plek om vol te staan en ' $n$ rol om te vervul. Lidmate het elkeen ' $n$ unieke deelnemings- en aanwendingsmoontlikheid, sodat die kerk haarself kan heroriënteer om in ' $n$ postchristelike tydvak steeds en al meer kerk van Jesus Christus te kan wees.

\section{Literatuurverwysings}

Berkhof, H 1985. Christelijk geloof. Nijkerk: Callenbach.

Codrington, G \& Grant-Marshall, S 2004. Mind the gap! South Africa: Penguin Group.

Coetzee, M 1997. ' $n$ Analise van die Myers-Briggs Type-Indicator Profiele in ' $n$ Postmodernistiese Organisasie. Pretoria: Universiteit van Pretoria.

Die Bybel, 1983. Nuwe Afrikaanse Vertaling (NAV). Kaapstad: NG-Kerk Uitgewers.

Heitink, G 2007. Een kerk met karakter - Tijd voor heroriëntatie. Kampen: Kok.

Hirsh, S K \& Kise, J A G 1997. Looking at Type and Spirituality. United States of America: Center for Applications of Psychological Type, Inc.

Myers, I B 1995. Gifts Differing: Understanding Personality Type. USA: Davies-Black Publishing.

-, 1998. Introduction to Type. $6^{\text {th }}$ ed. California: Consulting Psychologists.

Pieterse, H J C 1993. Praktiese Teologie as Kommunikatiewe Handelingsteorie. Pretoria: RGN-Uitgewers.

Steyn, C S 2008. Persoonlikheidstyle by erediensgangers: 'n Praktiesteologiese ondersoek na die uitdagings wat aan die liturg gestel word om erediensgangers van alle MBTI® persoonlikheidstyle effektief in eredienste te kan aanspreek. Ongepubliseerde doktorale proefskrif. Pretoria: Universiteit van Pretoria. 